\title{
USUCAPIÃO DE BENS PÚBLICOS DOMINICAIS
}

\section{ACQUISITION OF IMMOVABLE PROPERTY BELONGING TO THE STATE}

\author{
Marja Diane Pereira Brito de Oliveira ${ }^{1}$ \\ Vinicius Pinheiro Marques ${ }^{2}$
}

\section{RESUMO}

Estabelece o parágrafo $3^{\circ}$ do artigo 183 e o parágrafo único do artigo 191, ambos da Constituição Federal de 1988, que imóveis públicos não podem ser adquiridos por usucapião, e ainda o artigo 102 do Código Civil de 2002, dispõe que os bens públicos não estão sujeitos a usucapião. Neste sentido, que a doutrina majoritária e boa parte das jurisprudências brasileiras sustentam pela força normativa a posição, quanto à imprescritibilidade dos bens públicos. No entanto, apesar da vedação do referido instituto, surge o questionamento no ordenamento jurídico da possibilidade de se usucapir bens públicos à luz do princípio constitucional da função social da propriedade, consagrado em observância do artigo $5^{\circ}$, incisos XXII, XXIII e artigo 170, inciso III, expressos na referida Carta Magna. Baseando-se nesta abordagem, que o presente estudo visa analisar se os bens públicos dominicais podem ou não ser adquiridos por meio de usucapião, cabendo seu objetivo específico estudar a natureza jurídica dos bens públicos, compreender o princípio da função social da propriedade e verificar o posicionamento dos tribunais estaduais e superiores acerca da matéria. A metodologia empregada neste estudo será de natureza exploratória, valendo-se de dados doutrinários, jurisprudenciais e legais, e executados sob o método dedutivo, no intuito de verificar por meio da análise de textos e artigos, dentre outros, a aplicação dos conceitos e dispositivos legais à realidade fática da possibilidade de se usucapir bens públicos dominicais. Desta forma, conclui-se com o estudo que trata-se de matéria expressamente vedada constitucionalmente, no tocante ao usucapião de bens públicos, apesar disso, a pesquisa se propõe a aplicação do princípio da função social da propriedade e se destina a advogar a favor da tese de que, caso um bem público não cumpra sua função social, é possível usucapi-lo, embora haja divergência acerca da possibilidade ou não, de usucapir bens públicos no âmbito de bens dominicais.

\footnotetext{
${ }^{1}$ Bacharel em Direito pela Faculdade Católica do Tocantins e acadêmica do Programa de Pós-Graduação Lato Sensu em Direito e Processo Administrativo da Universidade Federal do Tocantins. Assistente em Administração da Fundação Universidade Federal do Tocantins - UFT. E-mail: marjadiane@ uft.edu.br

${ }^{2}$ Doutor em Direito pela Pontifícia Universidade Católica de Minas Gerais. Mestrando em Prestação Jurisdicional e Direitos Humanos pela Universidade Federal do Tocantins. Bacharel em Direito pela Universidade Federal de Juiz de Fora. Professor do Curso de Direito e da Pós-Graduação Lato Sensu em Direito e Processo Administrativo da Universidade Federal do Tocantins. E-mail: viniciusmarques@uft.edu.br.
} 
Palavras-chave: Aquisição de propriedade; bens públicos; função social.

\begin{abstract}
It establishes the third paragraph of article 183 and the sole paragraph of article 191, both of the Federal Constitution of 1988, that public real estate can not be acquired by "usucapião" provided for in Brazilian law, and also article 102 of the Civil Code of 2002, states that public assets are not Subject to "usucapião". In this sense, that the majority doctrine and a good part of the Brazilian jurisprudence maintain by the normative force the position, as to the imprescriptible of the public goods. However, despite the prohibition of said institute, the question arises in the legal system of the possibility of using public assets in the light of the constitutional principle of the social function of property, enshrined in compliance with article 5, paragraphs XXII, XXIII and article 170, subsection III, as expressed in the aforementioned Magna Carta. Based on this approach, the present study aims to analyze whether or not Sunday public assets can be acquired through "usucapião", its specific objective being to study the legal nature of public assets, to understand the principle of the social function of property and to verify the position of the state and higher courts on the matter. The methodology used in this study will be exploratory in nature, using doctrinal, jurisprudential and legal data, and performed under the deductive method, in order to verify through the analysis of texts and articles, among others, the application of concepts and devices To the factual reality of the possibility of using public goods belonging to the state. In this way, it concludes with the study that it is a matter expressly forbidden by the constitution regarding the use of public goods, despite this, the research proposes the application of the principle of the social function of property and is intended to advocate in favor of the thesis that, if a public good does not fulfill its social function, it is possible to use it, although there is disagreement as to whether or not to use public goods.
\end{abstract}

Keywords: Acquisition of property; Public goods; social role.

\title{
1. INTRODUÇÃO
}

A temática desenvolvida nesta pesquisa visa a explanar se há ou não a possibilidade de usucapir bens públicos, classificados como dominicais, à luz do princípio constitucional da função social da propriedade, muito embora o instituto do usucapião seja vedado pela legislação brasileira, no que tange aos bens públicos.

No direito brasileiro os assuntos envolvendo a posse ou o direito à propriedade é exercido com o objetivo de se efetivar a função social, e segundo a Constituição Federal ela deve permanecer em prol da sociedade. 
Para a pesquisa, é fundamental adentrarmos na esfera do direito civil apenas para se alcançar a pretensão do estudo, quanto aos bens públicos, como também com o fito de se observar o instituto do usucapião, que nada mais é que uma forma originária de aquisição de imóvel permitida por lei, tendo como objetivo atingir a função social da terra por aqueles que, atendendo a certos requisitos, garantem a estabilidade da propriedade.

As disposições que vedam o instituto do usucapião de bens públicos estão expressos nos artigos 183, parágrafo $\S 3^{\circ}$ e 191, parágrafo único da Constituição Federal de 1988 e artigo 102 do Código Civil de 2002. A partir destes dispositivos legais, a doutrina e jurisprudência majoritária, conforme entendimento da Corte do Supremo Tribunal Federal na súmula $n . \stackrel{0}{340}$, entendem as referidas vedações como gerais, considerando que até mesmo os bens que encontram-se desafetados sem nenhuma destinação pública não seriam passíveis de ser usucapidos.

No entanto, tal entendimento, desconsidera absolutamente o princípio constitucional da função social da propriedade, de tal modo que não resta justificada a proteção pelo interesse público, motivo este que afasta a sua aplicação devido a característica de ser um bem público. Constituindo assim, uma problemática ao qual está pesquisa cumpre a analisar.

Ressalta-se ainda que a discussão do tema proposto somente cabe a análise do referido princípio, quanto aos bens públicos dominicais não atribuindo sequer, qualquer apreciação as outras modalidades de bens públicos.

Assim, o presente estudo tem como objetivo geral averiguar se os bens públicos dominicais podem ou não ser adquiridos por meio de usucapião, sendo que o objetivo específico pauta-se em estudar a natureza jurídica dos bens públicos, compreender o princípio da função social da propriedade e verificar o posicionamento dos tribunais estaduais e superiores acerca da matéria.

A abordagem do assunto justifica-se devido a não permissão na esfera do direito brasileiro de se usucapir qualquer bem imóvel público, cuja abrangência tratase de bens dominicais, tendo em vista as ressalvas e restrições impostas pela Constituição Federal. 
Ademais, no âmbito jurídico alguns doutrinadores e juristas se manifestam de forma contrária ao que foi determinado pela mencionada Constituição, dessa forma, o fato de um bem público encontrar-se sem função social, enquanto poderia estar servindo a sociedade, fere o próprio interesse público.

Para a realização do trabalho, a metodologia utilizada foi de natureza exploratória, valendo-se de dados doutrinários, jurisprudenciais e legais, e executados sob o método dedutivo, no intuito de verificar por meio da análise de textos e artigos, dentre outros, a aplicação dos conceitos e dispositivos legais à realidade fática da possibilidade de se usucapir bens públicos dominicais.

Com isso, para melhor explicitar o tema proposto, esta pesquisa foi organizada em quatro capítulos.

No segundo capítulo, inicialmente, o trabalho aborda as principais definições relacionadas aos bens públicos, tais como os conceitos, classificação, regime jurídico e afetação e desafetação.

O terceiro capítulo contempla a análise acerca do princípio constitucional da função social da propriedade, regulado pelo artigo 5, inciso XXIII e artigo 170, inciso III.

E por último, o quarto capítulo, expõe o posicionamento dos tribunais estaduais e superiores acerca da matéria, atribuindo ao estudo as conclusões à respeito da aplicação do instituto do usucapião sob a ótica da função social da propriedade no tocante aos bens públicos dominicais.

\section{BENS PÚBLICOS: CONCEITO, CLASSIFICAÇÃO, REGIME JURÍDICO E AFETAÇÃO E DESAFETAÇÃO}

\subsection{Conceito e natureza jurídica dos bens públicos}

Inicialmente, compete acentuar que o conceito de bem público é dado pelo Código Civil de 2002, que em seu artigo 98 dispõe: "São bens públicos os bens do domínio nacional pertencentes às pessoas jurídicas de direito público interno; todos os outros são particulares, seja qual for a pessoa a que pertencerem". 
Desta maneira, definiram Alexandrino e Paulo (2013) que:

consoante o direito positivo brasileiro, só são formalmente bens públicos os bens de propriedade das pessoas jurídicas de direito público. Significa dizer que somente têm bens públicos propriamente ditos: a União, os estados, o Distrito Federal, os municípios e as respectivas autarquias e fundações públicas de natureza autárquica (ALEXANDRINO;PAULO, 2013, p.983/984).

Afirma ainda os referidos autores, que

os bens das pessoas jurídicas de direito privado integrantes da administração pública não são bens públicos, mas podem estar sujeitos a regras próprias do regime jurídico dos bens públicos, quando estiverem sendo utilizados na prestação de um serviço público (ALEXANDRINO;PAULO, 2013, p.985, grifos do autor).

Assim, os bens públicos são, de acordo com o art.98 do Código Civil de 2002, aqueles pertencentes as pessoas jurídicas de direito público. Tais bens, são tradicionalmente classificados tomando-se em conta três aspectos: quanto à titularidade; quanto à destinação e quanto à disponibilidade, o que se observará no subtítulo adiante.

\subsection{Classificação dos bens públicos}

\subsubsection{Quanto à titularidade}

Os bens públicos, como já tivemos oportunidade de examinar, pertencem à União, Estados e Municípios, que poderão transpassá-los a suas autarquias, conforme explicitado no item 2.1 deste estudo.

\subsubsection{Quanto à destinação}

Considerando o objetivo a que se destinam, os bens públicos classificam-se em: bens de uso comum do povo; bens de uso especial e bens dominicais. Essas 
três categorias de bens são assim descritas no art.99 do Código Civil vigente, os quais se discorrerá os dados mais significativos dessa classificação, como se segue.

Os bens de uso comum do povo, são aqueles destinados ao uso comum da população, "tais como rios, mares, estradas, ruas e praças" (art.99, I, do Código Civil), ou seja, trata-se dos logradouros públicos que se destinam à utilização geral pelos indivíduos (grifo nosso).

Nessa categoria, o que

prevalece é a destinação pública no sentido de sua utilização efetiva pelos membros da coletividade. Por outro lado, o fato de servirem a esse fim não retira ao poder público o direito de regulamentar o uso, restringindo-o ou até mesmo o impedindo, conforme o caso, desde que se proponha à tutela do interesse público (CARVALHO FILHO, 2010, p.1050, grifos do autor).

Os bens de uso especial, estão expressos no art.99, II, do Código Civil, trata-se dos bens, tais como "edifícios ou terrenos destinados a serviço ou estabelecimento da administração federal, estadual, territorial ou municipal, inclusive os de suas autarquias" (grifo nosso).

Significa dizer, que

são todos aqueles que visam à execução dos serviços administrativos e dos serviços públicos em geral. São os bens de propriedade das pessoas jurídicas de direito público utilizados para a prestação de serviços públicos (em sentido amplo). Exemplos de bens públicos de uso especial são: os edifícios públicos onde se situam repartições públicas, as escolas públicas, os hospitais públicos, os quartéis, os veículos oficiais, o material de consumo da administração, dentre outros. (ALEXANDRINO;PAULO, 2013, p.986, grifo nosso).

Quanto aos bens dominicais, na definição do art.99, III, do Código Civil, são os "que constituem o patrimônio das pessoas jurídicas de direito público, como objeto de direito pessoal, ou real, de cada uma dessas entidades" (grifo nosso).

Disposição do parágrafo único do art.99 do Código Civil, já citado assinala que: "Não dispondo a lei em contrário, consideram-se dominicais os bens pertencentes às pessoas jurídicas de direito público a que se tenha dado estrutura de direito privado".

Nas palavras de Lúcia Valle Figueiredo, 
nos bens dominicais estarão compreendidos, residualmente, todos aqueles que não sejam de uso comum do povo, quer por sua própria natureza, quer por sua destinação específica, ou de uso especial, afetados a qualquer serviço público. [...] estariam compreendidos todos os outros bens; somente à guisa de exemplo: terras devolutas, terrenos de marinha, a dívida ativa e etc(FIGUEIREDO, 2008, p.580).

Conceitua ainda Celso Antônio Bandeira de Mello que,

os bens dominicais, também chamados dominiais-são os próprios do Estado como objeto de direito real, não aplicados nem ao uso comum, nem ao uso especial, tais os terrenos ou terras em geral, sobre os quais tem senhoria, à moda de qualquer proprietário, ou que, do mesmo modo, lhe assistam em conta de direito pessoal. O parágrafo único do citado artigo pretendeu dizer que serão considerados dominicais os bens das pessoas da Administração indireta que tenham estrutura de direito privado, salvo se a lei dispuser em contrário. A redação do dispositivo é outra, e grosseiramente errada, visto que, de acordo com ela: "Não dispondo a lei em contrário, consideram-se dominicais os bens pertencentes às pessoas jurídicas de direito público a que se tenha dado estrutura de direito privado". Ora, não há, nem pode haver, pessoa de direito público que tenha estrutura de direito privado, pois a estrutura destas entidades auxiliares é um dos principais elementos para sua categorização como de direito público ou de direito privado (MELLO, 2006,p.867, grifo nosso).

Desse modo, se o bem, portanto, serve ao uso público em geral, ou se presta à consecução das atividades administrativas, não serão enquadrados como dominicais.

\subsubsection{Quanto à disponibilidade}

Essa classificação tem por finalidade distinguir os bens públicos em: bens indisponíveis; bens patrimoniais indisponíveis e bens patrimoniais disponíveis. Sob esse prisma, se observará a análise adiante.

Destaca Filho (2008) que os bens indisponíveis são aqueles que não assumem caráter tipicamente patrimonial e que são insuscetíveis de alienação pelo poder público, por esse motivo as pessoas a que pertencem não podem deles dispor (grifo nosso).

Afirma ainda Alexandrino; Paulo (2013) inclui-se, então, como indisponíveis os bens de uso comum do povo, como regra geral, sendo os mares, rios, estradas, 
as praças, logradouros públicos, o espaço aéreo etc., alguns deles, é óbvio, enquanto mantiverem esta natureza.

Ademais, os bens patrimoniais indisponíveis se ressalta o caráter patrimonial do bem, ou seja, a sua possibilidade de ser economicamente avaliado e a sua indisponibilidade, que resulta, não da natureza do bem, mas do fato de estar ele afetado a um fim público (DI PIETRO, 2009, grifo nosso).

E por fim, os bens patrimoniais disponíveis "são os bens dominicais em geral, porque não se destinam ao público em geral, nem são utilizados para o desempenho normal das atividades administrativas" (CARVALHO FILHO, 2008, p.1054, grifo nosso).

Assim sendo, por não estarem os bens afetados a certa finalidade pública, podem ser alienados, conforme explana o vigente Código Civil, que "os bens públicos dominicais podem ser alienados, observados as exigências da lei” (art.101).

\subsection{Regime Jurídico dos bens públicos}

Os bens públicos envolvem certos atributos para que seja assegurado o interesse público. Entre as principais características temos a inalienabilidade, impenhorabilidade e imprescritibilidade:

\subsubsection{Quanto à inalienabilidade}

Pela redação do artigo 100 do Código Civil de 2002, "os bens públicos de uso comum e os de uso especial são inalienáveis, enquanto conservarem a sua qualificação, na forma que a lei determinar". E, pelo artigo 101, "os bens dominicais podem ser alienados, observados as exigências da lei".

Com relação aos bens de uso comum e de uso especial. De acordo com Maria Sylvia Zanella Di Pietro esclarece que: 
privado, não podendo ser objeto de relações jurídicas regidos pelo Direito Civil, como compra e venda, doação, permuta, hipoteca, locação, comodato. Para serem alienados pelo método de direito privado, têm de ser previamente desafetados, ou seja, passar para a categoria de bens dominicais, pela perda de sua destinação pública. Vale dizer que a inalienabilidade não é absoluta (DI PIETRO, 2009, p.680/681, grifos da autora).

Importante ressaltar que, os bens dominicais, só poderá ser objeto de alienação, caso obedecidos os requisitos legais. Os requisitos para alienação de bens públicos constam no artigo 17 da Lei $n$. 0 8.666/1993, que exige demonstração do interesse público, prévia avaliação, licitação e, caso se trate de bem imóvel, autorização legislativa.

\subsubsection{Quanto à impenhorabilidade}

No que tange, ao instituto da penhora trata-se de ato de natureza constritiva que, no processo recai sobre bens do devedor para propiciar a satisfação do credor no caso do não cumprimento da obrigação. Nesse sentido, Carvalho Filho (2010, p.1058) ensina que:

A impenhorabilidade tem o escopo de salvaguardar os bens públicos
desse processo de alienação, comum aos bens privados. Com efeito,
admitir-se a penhora de bens públicos seria o mesmo que admitir sua
alienabilidade nos moldes do que ocorre com os bens particulares
em geral. A característica, por conseguinte, tem intuito
eminentemente protetivo.

Desta forma, consoante o referido autor, claro está que os bens públicos, porém, não se sujeitam ao regime da penhora, e por esse motivo são caracterizados por impenhoráveis. A impenhorabilidade tem lastro constitucional, conforme dispõe o art.100 da Constituição Federal de 1988.

\subsubsection{Quanto à imprescritibilidade}

Conforme expresso na Constituição Federal vigente, nos artigos 183, § 3ํㅡ, e 191, parágrafo único, "os imóveis públicos não serão adquiridos por usucapião". Também é válido mencionar a dicção da súmula 340 do STF, que revela: "Desde a 
vigência do Código Civil os bens dominicais e os demais bens públicos não podem ser adquiridos por usucapião".

Sob essa ótica, Alexandrino; Paulo (2013, p.992) entende que:

Assim, mesmo que um particular tenha a posse pacífica de um bem público pelo tempo necessário à aquisição por usucapião dos bens privados, conforme regulado no direito privado, ou por qualquer período de tempo, a bem da verdade, não adquirirá direito de propriedade sobre esse bem.

Constata-se, dessa forma, por meio dos dispositivos legais demonstrados a negativa da possibilidade de usucapião de bens públicos, o que evidencia que grande parte da doutrina prevalece nessa linha de raciocínio.

\subsection{Afetação e desafetação dos bens públicos}

O tema da afetação e da desafetação diz respeito aos fins para os quais está sendo utilizado o bem público.

Segundo Dalvi (2009) a afetação é a propriedade do bem público que tem sua destinação efetivada; a desafetação é a retirada da destinação pública, dando-Ihe o caráter de disponível para alienação.

Na lição do estudioso José dos Santos Carvalho Filho esclarece o assunto, com o seguinte exemplo:

Um prédio onde haja uma Secretaria de Estado em funcionamento pode ser desativado para que o órgão seja instalado em local diverso. Esse prédio, como é lógico, sairá de sua categoria de bem de uso especial e ingressará na de bem dominical. A desativação do prédio implica sua desafetação. Se, posteriormente, no mesmo prédio for instalada uma creche organizada pelo Estado, haverá afetação, e o bem, que estava na categoria dos dominicais, retornará à sua condição de bem de uso especial (CARVALHO FILHO, 2010, p.1055).

Dessa forma, é relevante a ocorrência em si da alteração da finalidade, significando, que na afetação o bem passa a ter uma destinação pública que não 
ISSN no 2359-0106

Vol. 4, n. 1, 2017.

tinha, e que na desafetação se dá o fenômeno contrário, ou seja, o bem, que tinha a destinação pública, passa a não mais tê-la, temporária ou definitivamente.

\section{FUNÇÃO SOCIAL DA PROPRIEDADE}

Pelos ditames do Estado Democrático de Direito, no que está positivado na Constituição Federal de 1988, pelos artigos 5ำ, inciso XXIII; 170, inciso III, 182 e 186, estão previstos o princípio da função social como patamar de direito fundamental. Os dois últimos artigos, respectivamente, atendem a função social da propriedade urbana e rural.

A função social de propriedade é reconhecida constitucionalmente como direito fundamental, com o fito de atender ao interesse público. Assim ensina Maria Helena Diniz:

A Constituição Federal, no art.5ำ XXII, garante o direito de propriedade, mas requer, como vimos, que ele seja exercido atendendo a sua função social. Com isso, a função social da propriedade a vincula não só à produtividade do bem, como também aos reclamos da justiça social, visto que deve ser exercida em prol da coletividade. [...]. O princípio da função social da propriedade está atrelado, portanto, ao exercício e não ao direito de propriedade (DINIZ, 2010, p.107, grifo meu).

Dentro deste conceito, aduz ainda a citada doutrinadora Diniz (2010) que o próprio Código Civil de 2002 se comprometeu a zelar pela função social da propriedade por meio do artigo 1228, parágrafos $1^{\circ}$ a $5^{\circ}$, uma vez que afasta 0 individualismo, coibindo o uso abusivo da propriedade, que deve ser utilizada para o bem comum.

Baseado o assunto na concepção de bens públicos, é cediço que o direito à propriedade é exercido com a finalidade de se concretizar a função social, e consoante a Carta Magna ela deve existir em prol da sociedade, bem como o Código Civil discorre sobre o assunto expondo que a propriedade deve ser utilizada visando o bem comum. 
Nesse passo, a previsão constitucional supramencionada não alude na impossibilidade de ser aplicado o princípio constitucional da função social da propriedade aos bens públicos, pode-se dizer aqueles que se caracterizam como dominicais.

Corrobora a este entendimento, de que os bens públicos é primordial o cumprimento da função social a lição da autora Cristiana Fortini, nestes termos:

\begin{abstract}
A Constituição da República não isenta os bens públicos do dever de cumprir função social. Portanto, qualquer interpretação que se distancie do propósito da norma constitucional não encontra guarida. Não bastasse a clareza do texto constitucional, seria insuscetível conceber que apenas os bens privados devam se dedicar ao interesse social, desonerando-se os bens públicos de tal mister. Aos bens públicos, com maior razão de ser, impõe-se o dever inexorável de atender à função social (FORTINI, 2004, p.117 apud GUIMARÃES, [s.p.]).
\end{abstract}

Nas Palavras da Defensora Pública Federal, Karine de Carvalho Guimarães ([s.a.], [s.p.]), "a propriedade pública dissociada de sua função social não possui fundamento constitucional, não sendo, portanto, objeto de tutela e legitimidade".

Esclarece ainda a citada autora Cristiana Fortini, que:

A Constituição da República, ao afastar a possibilidade de usucapião de bens públicos, pretendeu acautelar os bens materialmente públicos, ou seja, aqueles que, pela função a que se destinam, exijam proteção, sob pena de sacrificar o interesse público. Interpretação diversa se distancia da correta exegese da Constituição da República porque implica a mitigação da exigência constitucional de que a propriedade pública e a privada cumpram função social(FORTINI, 2004, p.117 apud GUIMARÃES, [s.p.]).

Percebe-se que, o princípio da função social da propriedade tem o propósito constitucional de atender a sociedade, por sua vez o bem público dotado desta função cumpre uma utilidade pública específica e, caso não promova determinado papel, mister se faz que o imóvel público seja suscetível ao desempenho da finalidade pública, de modo servir à função social. 


\title{
4. POSICIONAMENTO DOS TRIBUNAIS ESTADUAIS E SUPERIORES ACERCA DO USUCAPIÃO DE BENS PÚBLICOS DOMINICAIS
}

As pretensões de reconhecimento da prescrição aquisitiva sobre os bens públicos tem sido rejeitadas pelos tribunais com base no que prescrevem os mencionados artigos 183, §3ํ e 191, § único da Constituição Federal de 1988 e artigo 102 do Código Civil. A referida vedação é assim entendida devido a proteção especial atribuída aos bens públicos, no entanto tal embasamento não apresenta exceções a aludida regra.

Por essa razão, grande parte da doutrina majoritária e jurisprudência não considera a possibilidade de usucapião de bens públicos, sob nenhum argumento, nem ao menos sob o enfoque do princípio constitucional da função social da propriedade. Já que o assunto fora sumulado pelo Supremo Tribunal Federal n.. 340, o que mais uma vez contrária a matéria em questão.

Sob essa ótica, resta evidente a dúvida quanto a aplicação do aludido princípio, se deve o princípio da função social da propriedade ser apreciado somente pelo particular, ou também merece a devida observação do poder público?

Sobre isso explica, Elder Luís dos Santos Coutinho em seu artigo, da possibilidade de usucapião de bens formalmente públicos:

\begin{abstract}
A aparente dúvida é rechaçada no instante em que se recorda que o Estado Democrático de Direito não é permitido se furtar do respeito às suas próprias normas. Ademais, pela própria denominação do "bem público" já se percebe que o "verdadeiro", ou seja, aquele afetado à destinação pública, está necessariamente em consonância ao princípio da função social da propriedade. A problemática reside na prática, em que vários bens ditos públicos, não possuem afetação. É justamente aí que jaze o descumprimento da função social da propriedade por parte do poder público, o que, para alguns, geraria a possibilidade de aquisição do bem por usucapião (COUTINHO, [s.p.\}).
\end{abstract}

Deste modo, fica claro, que se um imóvel público num Estado Democrático não atende a sua função social, ele, mais do que o privado, deve sofrer as mesmas 
penalidades inerentes ao proprietário particular, devido a sua inércia ou abandono do bem, vindo a acarretar a sua perda/aquisição por meio de usucapião.

Dessa maneira, a doutrina majoritária exalta o entendimento de que bens públicos não poderão ser usucapidos, como os autores José dos Santos Carvalho Filho, Marcelo Alexandrino e Vicente Paulo, Celso Antônio Bandeira de Mello, Luciano Dalvi, Maria Sylvia Zanella DI Pietro e dentre muitos outros. Entretanto, há aqueles que classificam os bens em formais e materiais, consideram os bens formais passíveis de usucapião.

Interessante notar que, este é um posicionamento minoritário que defende a tese da possibilidade de se usucapir bens públicos, entre eles estão os doutrinadores Cristiano Chaves de Farias e Nelson Rosenvald, cuja defesa discorre, nestes termos:

Por fim, o art.102 do Código Civil adverte que os bens públicos não estão sujeitos a usucapião. O legislador foi radical ao deixar claro que a impossibilidade de usucapião atinge todos os bens públicos, seja qual for a natureza ou a finalidade. A nosso viso, a absoluta impossibilidade de usucapião sobre bens públicos é equivocada, por ofensa ao princípio constitucional da função social da posse e, em última instância, ao próprio princípio da proporcionalidade. Os bens públicos poderiam ser divididos materialmente e formalmente públicos. Estes seriam aqueles registrados em nome da pessoa jurídica de direito público, porém excluídos de qualquer forma de ocupação, seja para moradia ou exercício de atividade produtiva. Já os bens materialmente públicos seriam aqueles aptos a preencher critérios de legitimidade e merecimento, postos dotados de alguma social.

Porém, a Constituição Federal não atendeu a esta peculiaridade, olvidando-se de ponderar o direito fundamental difuso à função social com o necessário dimensionamento do bem público, de acordo com a sua conformação, no caso concreto. Ou seja: se formalmente público seria possível a usucapião satisfeito os demais requisitos; sendo materialmente público haveria óbice à usucapião. Esta seria a forma mais adequada de tratar a matéria, se lembrarmos, enquanto o bem privado" tem" função social, o bem público "é" função social (FARIAS; ROSENVALD, 2006, p.267/268, grifo meu). 
Nessa linha de raciocínio, em sua obra "Curso de Direito Administrativo" Bastos (1999) também deixa claro seu posicionamento:

A imprescritibilidade diz respeito a aquisição da propriedade por usucapião. Os bens públicos não podem ser usucapidos. A Constituição da República textualmente proíbe a aquisição de móveis públicos urbanos (art.183, § $3^{\circ}$ ) e rurais art.191, §3ํ) por usucapião. Esta proibição não se aplica aos bens dominicais, que nada obstante serem públicos em razão da qualidade que detêm a sua titularidade, são possuídos pelos poderes públicos à moda de um particular, submetidos, inclusive, ao regime de direito privado. Esses são usucapíveis. (BASTOS, 1999, p.311).

O estudioso Elder Luís dos Santos Coutinho em seu artigo, da possibilidade de usucapião de bens formalmente públicos faz menção a divisão dos bens públicos, consoante os citados autores da seguinte forma:

Os bens materiais seriam aqueles bens públicos por excelência, já que destinados a função público- social. Já os bens públicos formais, contrariamente, seriam aqueles desafetados de qualquer destinação pública, ou seja, públicos pela simples designação legal, os quais no entendimento de alguns doutrinadores seriam prescritíveis e consequentemente passíveis de aquisição por usucapião, em respeito ao princípio da função social da propriedade (COUTINHO, [s.p.], grifo meu).

Vê-se, então, que os referidos autores acreditam que não é a personalidade jurídica do titular do bem que determinará sua natureza, mas a destinação de suas finalidades a um serviço público, notadamente, se o bem público cumpre uma função social.

Demonstradas estas considerações, importante se faz deixar evidente que a jurisprudência dominante apresenta o entendimento consolidado de que é incabível a possibilidade de usucapião de bens públicos, conforme se depreende das ementas das decisões proferidas pelo Superior Tribunal Federal e o Superior Tribunal de Justiça, como adiante se vê (grifo meu): 
INDENIZAÇÃO POR BENFEITORIAS.MERA DETENÇÃO. INAPLICABILIDADE. AGRAVO REGIMENTAL QUE NÃO ATACA FUNDAMENTO DA DECISÃO IMPUGNADA. SÚMULA N. 182/STJ. INOVAÇÃO RECURSAL. INADMISSIBILIDADE. FALTA DE PREQUSESTIONAMENTO. DECISÃO MANTIDA.

1. "Os imóveis administrados pela Companhia Imobiliária de Brasília (TERRACAP) são públicos, sendo insuscetíveis de usucapião" (EREsp 695.928/DF, Rel. Ministro JOSÉ DELGADO, CORTE ESPECIAL, julgado em 18/10/2006, DJ 18/12/2006, p. 278).2. A indevida ocupação de bem público descaracteriza posse, qualificando mera detenção, de natureza precária, que inviabiliza a pretensa indenização por benfeitorias. Precedentes.3. É inviável o agravo interno que deixa de atacar especificamente os fundamentos da decisão agravada. Incidência, por analogia, do obstáculo de que trata a Súmula n. 182/STJ.4. Não se conhece de questão jurídica ventilada tão somente em sede de agravo interno, que revela inadmissível inovação recursal.5. O dispositivo legal que não fora previamente analisado na instância ordinária não preenche o requisito do prequestionamento.Aplicação analógica da Súmula n. 282/STF.6. Agravo regimental a que se nega provimento.(STJ- AgRg no REsp 851.906/DF, Rel. Ministro ANTONIO CARLOS FERREIRA, QUARTA TURMA, julgado em 04/12/2014, DJe 11/12/2014) (grifo nosso).

DIREITO CIVIL E PROCESSUAL CIVIL. RECURSO ESPECIAL. OMISSÃO.INEXISTÊNCIA. USUCAPIÃO. MODO DE AQUISIÇÃO ORIGINÁRIA DAPROPRIEDADE. TERRENO DE MARINHA. BEM PÚBLICO. DEMARCAÇÃO POR MEIO DEPROCEDIMENTO ADMINISTRATIVO DISCIPLINADO PELO DECRETO-LEI N.9.760/1946. IMPOSSIBILIDADE DE DECLARAÇÃO DA USUCAPIÃO, POR ALEGAÇÃOPOR PARTE DA UNIÃO DE QUE, EM FUTURO E INCERTO PROCEDIMENTO DEDEMARCAÇÃO PODERÁ SER CONSTATADO QUE A ÁREA USUCAPIENDA ABRANGE AFAIXA DE MARINHA. DESCABIMENTO.

1. Embora seja dever de todo magistrado velar a ConstituiçãoFederal, para que se evite supressão de competência do egrégio STF,não se admite apreciação, em sede de recurso especial, de matériaconstitucional, ainda que para viabilizar a interposição de recursoextraordinário.

2. A usucapião é modo de aquisição originária da propriedade,portanto é descabido cogitar em violação ao artigo 237 da Lei6.015/1973, pois o dispositivo limita-se a prescrever que não sefará registro que dependa de apresentação de título anterior, a fimde que se preserve a continuidade do registro. Ademais, a sentençaanota que o imóvel usucapiendo não tem matrícula no registro deimóveis.

3. Os terrenos de marinha, conforme disposto nos artigos 1ํㅡ, alíneaa, do Decreto-lei 9.760/46 e 20, VII, da Constituição Federal, são bens imóveis da União, necessários à defesa e à segurança nacional,que se estendem à distância de 33 metros para a área terrestre,contados da linha do preamar médio de 1831. Sua origem remonta aostempos 
coloniais, incluem-se entre os bens públicos dominicais depropriedade da União, tendo o Código Civil adotado presunçãorelativa no que se refere ao registro de propriedade imobiliária,por isso, em regra, o registro de propriedade não é oponível à União4. A Súmula 340/STF orienta que, desde a vigência do Código Civil de1916, os bens dominicais, como os demais bens públicos, não podemser adquiridos por usucapião, e a Súmula 496/STJ esclarece que "osregistros de propriedade particular de imóveis situados em terrenosde marinha não são oponíveis à União".

[...]

8. Recurso especial a que se nega provimento. (STJREsp1090847/RS- Ministro relator: LUIS FELIPE SALOMÃO (1140)T4- QUARTATURMA- Julgamento em 23/04/2013- Dj 10/05/2013) (grifo nosso).

EMENTA: AGRAVO REGIMENTAL NO AGRAVO DE INSTRUMENTO. CIVIL E PROCESSUAL CIVIL. USUCAPIÃO. BEM DOMINICAL. SUPOSTA AQUISIÇÃO EM DATA ANTERIOR AO REGISTRO DO BEM PELA UNIÃO. REEXAME DE FATOS E PROVAS. SÚMULA N. 279 DO STF. INVIABILIDADE DO RECURSO EXTRAORDINÁRIO.

1. A Súmula 279/STF dispõe: "Para simples reexame de prova não cabe recurso extraordinário". 2. É que o recurso extraordinário não se presta ao exame de questões que demandam revolvimento do contexto fático-probatório dos autos, adstringindo-se à análise da violação direta da ordem constitucional. 3. In casu, o acórdão recorrido assentou: "ADMINISTRATIVO. AÇÃO DE USUCAPIÃO. BEM DOMINICAL. IMPOSSIBILIDADE DE ALIENAÇÃO. 1. A área objeto da presente ação constitui bem publico dominical, sobre o qual não pode incidir usucapião, nos termos dos arts. $183, \S$ 3ㅜ, e 191, parágrafo único, da Constituição Federal. 2. Em que pese a demonstração pelo autor da posse mansa e pacífica do bem por período superior a vinte anos, sendo o imóvel propriedade da União, impossível a sua aquisição pela usucapião." 4. Agravo regimental a que se nega provimento. (STF-Al-852804 AgR/SC- Relator Ministro LUIZ FUX- PRIMEIRA TURMAJulgamento em 04/12/2012) (grifo nosso).

Resta evidente, como já dito, que a jurisprudência dominante não admite usucapião de bens públicos, inclusive na modalidade de bens públicos dominicais.

Ao contrário do entendimento dos tribunais superiores, há aqueles que entendem ser possível se admitir usucapião de bens públicos. Nesse sentido, vejase o seguinte julgado da 5 ${ }^{\text {a }}$ Câmara Cível do Tribunal de Justiça de Minas Gerais, referente à apelação cível n.ำ 1.0194.10.011238-3/001/MG, que trata-se do 
relator(a): Des.(a) Barros Levenhagen, datado de 08/05/2014(online, grifo nosso), in verbis:

EMENTA: APELAÇÃO CIVIL - AÇÃO REIVINDICATÓRIA -
DETENÇÃO - INOCORRENNCIA - POSSE COM "ANIMUS DOMINI" -
COMPROVAÇÃO - REQUISITOS DEMONSTRADOS -
PRESCRIÇÃO AQUISITIVA - EVIDÊNCIA - POSSIBILIDADE -
EVIDÊNCIA - PRECEDENTES - NEGAR PROVIMENTO.

- "A prescrição, modo de adquirir domínio pela posse contínua (isto é, sem intermitências), ininterrupta (isto é, sem que tenha sido interrompida por atos de outrem), pacífica (isto é, não adquirida por violência), pública (isto é, exercida à vista de todos e por todos sabida), e ainda revestida com $o$ animus domini, e com os requisitos legais, transfere e consolida no possuidor a propriedade da coisa, transferência que se opera, suprindo a prescrição a falta de prova de título preexistente,ousanando o vício do modo de aquisição".

Da mesma forma, é o entendimento deste Eg. Tribunal de Justiça pelo julgado da 1a Câmara Cível, referente à Apelação Cível n.ำ 1.0012.04.001688-8/001/MG, que trata-se do relator(a): Des.(a) Eduardo Andrade, datado em 27/04/2010 (online, grifo nosso), como segue:

EMENTA: AÇÃO DE USUCAPIÃO - BEM IMÓVEL - ÁREA MARGINAL À RODOVIA ESTADUAL - IMPUGNAÇÃO DO DER/MG - RESPEITO À FAIXA DE DOMÍNIO - REGULAMENTAĈ̃O DA LEI QUE EXIGE RESERVA DA ÁREA - AUSẾNCIA DE COMPROVAÇÃO - INEFICÁCIA POSITIVA DA NORMA INAPLICABILIDADE. RESPEITO À "'AREA NON AEDIFICANDI"' USUCAPIÃO - POSSIBILIDADE - MERA IMPOSIÇÃO DE LIMITAÇÃO ADMINISTRATIVA - RECURSO DESPROVIDO DECISÃO CONFIRMADA.

- Não restando provada a regulamentação, pelo DER/MG (ente com circunscrição sobre a rodovia estadual), da lei que contém disciplina geral acerca da reserva de 'faixa de domínio' de áreas marginais a rodovias estaduais, impõe-se reconhecer a ineficácia positiva da norma, ante a ausência de parâmetros objetivos acerca da identificação e demarcação da área. - A exigência legal de reserva de faixa não-edificável de 15 metros de cada lado das rodovias implica mera limitação administrativa, com imposição de obrigação de não-fazer, não representando óbice, portanto, à usucapião da respectiva área. 
No mesmo passo é o entendimento da 9a Câmara de Direito Privado do Tribunal de Justiça de São Paulo que considera que um bem público pode ser objeto de ação de usucapião por uma empresa. A decisão vale apenas para casos que envolvam bem dominical já desafetado, ou seja, aqueles que não servem ao uso comum ou especial, conforme demonstra na íntegra o Acordão de registro n. $=2012.0000303597$, em que se discute os Embargos Infringentes $\mathrm{n}$. 9172311-97.2007.8.26.0000/50000- SP, Relatora Lucila Toledo, Julgado em 22/05/2012 (grifo nosso).

Desta feita, sabe-se que as partes contrarias as decisões proferidas podem recorrer até a última instância para julgamento, no entanto, importante se faz considerar o grande "salto jurídico", quanto a interpretação da norma nesses casos concretos, uma vez que a tentativa se desenvolve a fim de se resguardar o direito na fática realidade social brasileira, considerando o entendimento pela possibilidade de usucapião de um bem público dominical, tendo em vista a função social da propriedade.

\section{CONCLUSÃO}

Ante o exposto, vê-se que a vedação da prescrição aquisitiva aos bens públicos é enfrentada de modo absoluto, sem a excepcionalidade à regra normativa, logo o que prevalece como se viu é a imprescritibilidade desses bens.

Nota-se que grande parte da doutrina e do próprio entendimento sumulado do Supremo Tribunal Federal, e com isso dá grande parte dos tribunais estaduais, é quanto a inadmissibilidade do usucapião de bens públicos, tão logo jurisprudências não admitam se usucapir com base nos dispositivos legais já demonstrados.

Dessa forma, como se vê, a matéria é de entendimento controverso, uma vez que parte minoritária da doutrina e alguns tribunais estaduais, que defendem a usucapião de bens públicos se baseia na função social, o que não é nenhum equívoco ou ofensa aos princípios constitucionais, posto que, se compete aos particulares, deve caber também ao poder público fazer dos seus bens algo útil. 
A Constituição Federal vigente prima pelos direitos iguais, não sendo admissível que exista esse tipo de contradição, ao deixar um vasto espaço de terra ou prédios abandonados dentre outros, sem utilidade só pelo fato de haver garantia constitucional de que esse bem não poderá ser fruto de usucapião, e assim prolongar a ausência de destinação por anos.

Logo, é possível defender a ideia de que seria admissível se usucapir bens públicos dominicais, destinados a uma finalidade pública, visto que estão desafetados, sem função social, já que trata-se de imóveis desativados, abandonados ou pode-se dizer sem utilidade específica para o ente público.

Sendo assim, é importante que o poder público seja incomodado, a fim de impedir atuar com desídia ou omissão, quanto aos bens públicos dominicais, desafetados, sem nenhuma perspectiva de utilização para o interesse público, bem como os Tribunais poderiam ousar em apoiar a exceção aos casos concretos, usando-se da interpretação as regras da imprescritibilidade dos bens públicos, de acordo com a destinação do bem, cujo fulcro é garantido de acordo com o princípio da função social da propriedade.

\section{REFERÊNCIAS}

ALEXANDRINO, Marcelo; PAULO,Vicente. Direito administrativo descomplicado. 21ed.rev. e atual.- Rio de Janeiro: Forense; São Paulo: Método, 2013.

BASTOS, Celso Ribeiro, Curso de Direito Administrativo. 3 ed. São Paulo: Saraiva, 1999.

BRASIL. Constituição da República Federativa do Brasil. São Paulo: Saraiva, 2013.

LEI n. 10.406, de 10 de janeiro de 2002. Lei de introdução ao código civil brasileiro. Disponível em: <http://www.planalto.gov.br/ccivil 03/leis/2002/L10406>. htm. Acesso em: 21/01/2015.

CARVALHO FILHO, Manual de direito administrativo, 24 ed. Rio de Janeiro: Lumen Juris, 2010. 
COUTINHO, Elder Luis dos Santos. Da possibilidade de usucapião de bens formalmente públicos. In Convibra 09. Disponível em: <http: www.convibra.com.br>. Acesso em: 29/01/2015.

DALVI, Luciano. Direito administrativo, Leme: J.H. Mizuno, 2009.

DINIZ, Maria Helena. Curso de direito civil brasileiro. 25.ed - São Paulo: Saraiva, 2010;

DI PIETRO, Maria Sylvia Zanella Di. Direito Administrativo. 22 ${ }^{a}$ ed. São Paulo: Atlas, 2009.

FARIAS, Cristiano Chaves; ROSENVALD, Nelson. Direitos Reais. Rio de Janeiro: Lumem Juris, 2006.

FIGUEIREDO, Lúcia Valle, Curso de Direito Administrativo. 9a ed. São Paulo, 2008.

FORTINI,Cristiana. A função social dos bens públicos e o mito da imprescritibilidade. Revista Brasileira de Direito Municipal, Belo Horizonte, ano 5, n.12, p.abril/junho, 2004.

GUIMARÃES, Karine de Carvalho. A função social da propriedade e a vedação de usucapião sobre bens públicos. Uma interpretação à luz da unidade constitucional. Disponível em: <http: //jus.com.br/artigos/10948>. Acesso em: 29/01/2015.

MARCONI, Marina de Andrade; LAKATOS, Eva Maria. Fundamentos de metodologia científica. São Paulo: Atlas, 2010;

MELLO, Celso Antônio Bandeira de. Curso de Direito Administrativo. 21 ed. São Paulo: Malheiros, 2006 